Original Research Paper

\title{
Antimicrobial Resistance in Bacterial Pathogens of Canine Otitis
}

\author{
${ }^{1}$ Ricardo Antonio Pilegi Sfaciotte, ${ }^{2}$ Jéssica Taina Bordin, ${ }^{2}$ Vanessa Kelly Capoia Vignoto, \\ ${ }^{2}$ Patrícia Marques Munhoz, ${ }^{2}$ Adriana Aparecida Pinto, ${ }^{2}$ Maria José Baptista Barbosa, \\ ${ }^{2}$ Rejane Machado Cardozo, ${ }^{1}$ Sílvia Cristina Osaki and ${ }^{2}$ Sheila Rezler Wosiacki \\ ${ }^{1}$ Animal Science Pós-graduate Program, Federal University of Parana, Campus Palotina, Parana, Brazil \\ ${ }^{2}$ Department of Veterinary Medicine, State University of Maringa, Parana, Brazil
}

Article history

Received: 18-09-2014

Revised: $15-02-2015$

Accepted: 22-06-2015

Corresponding Auhtor: Sheila Rezler Wosiacki Department of Veterinary Medicine, State University of Maringa, Estrada da Paca, s/n, 87507-190, Umuarama, Parana, Brazil

Tel: +55 44 3621-9412 Email: srwosiacki@uem.br
Abstract: Otitis is one of the most frequent infections in dogs. This is attributed to the misuse of drugs enabling generation of multi-resistant micro-organisms. The emergence of multiresistant bacterial strains in veterinary medicine is a reality that must be studied and evaluated by the professionals. The objective of this study was to isolate and evaluate the antimicrobial susceptibility of bacterial pathogens of otitis in dogs. Otologic swabs were collected from 36 dogs with clinical otitis. 41 bacterial strains were isolated and antimicrobial susceptibility tests were performed by disk diffusion method with 34 antimicrobial agents. Presence of the resistance gene mecA of Staphylococcus was examined for 22 strains of staphylococci by PCR. A total of 1108 ratings antimicrobial agents were performed. The percentage of drug resistance was $34.66 \%(n=384)$ of the assessments with partial or total resistance. Major bacterial pathogens were Staphylococcus spp. (65.85\%), Pseudomonas spp. (12.19\%) and Enterobacteria species (19.51\%). $53.66 \%$ of the isolates were considered multiresistant. Antimicrobial agents considered most resistant in the strains studied were penicillin (75.00\%), tetracyclin $(50.00 \%)$, amoxicillin (48.78\%), trimethoprimsulfamethoxazole (46.15\%), clindamycin and rifampicin (43.24\%). 11 strains were phenotypically characterized as MRS, 4 genotypically as MRS, 2 as MLSB-MRS and 2 as gram negative ESBL-producing.

Keywords: Otitis, Canine, Pathogens, Antimicrobial Resistance, Staphylococcus

\section{Introduction}

Otitis is one of the most frequent infections in dogs. It is a disease of multifactorial causes and can manifest acutely or chronically. Predisposing factors such as anatomical conformations of both the ear canal and the ears, changes in microflora and immune suppression are some of the main observed.

The normal ear canal microflora is varied consisting of coagulase-positive and coagulase-negative Staphylococcus spp., $\beta$-haemolytic Streptococcus spp., Proteus spp., Escherichia coli and Pseudomonas spp. (Hariharan et al., 2006; Petrov et al., 2013). Changes to this microflora can lead to the development of opportunistic and also pathogenic bacteria (Oliveira et al., 2012).
According to (Oliveira et al., 2012; Oliveira et al., 2005; 2006b) main bacterial pathogens of canine otitis are Staphylococcus and Pseudomonas species. Other bacterial species found in smaller percentages are Streptococcus, Escherichia coli, Proteus and Enterococcus species (Hariharan et al., 2006).

Frequently observed failure of treatment of ear infections. This is attributed to the misuse of drugs enabling generation of multi-resistant micro-organisms, that result in reduced efficacy of the drugs. This occurrence has increased concomitantly with routine use of antibiotics, especially broad-spectrum drugs that are able to act on a large number of bacterial species. Not performing tests for agent identification and 
susceptibility favors the generation of resistant strains, making it essential to carry out these (Ishii et al., 2011).

The emergence of multiresistant bacterial strains in veterinary medicine is a reality that must be studied and evaluated by the professionals.

The objective of this study was to isolate and evaluate the antimicrobial susceptibility of bacterial pathogens of otitis in dogs.

\section{Materials and Methods}

\section{Sample Collection}

Otologic swabs were collected from 36 dogs with clinical otitis in the Veterinary Hospital of State of Maringá, Brazil between March, 2012 and September, 2014. The samples were initially incubated in Brain Heart Infusion broth - BHI $\left(\mathrm{OXOID}^{\circledR}\right)$ at $36^{\circ} \mathrm{C}$ for 2 to 18 hours, then plated on Blood agar (5\% sheep blood defibrillated in Nutrient Agar-OXOID $\left.{ }^{\circledR}\right)$ and MacConkey agar $\left(\mathrm{OXOID}^{\circledR}\right)$, incubated at $36^{\circ} \mathrm{C}$ for $24 / 48 \mathrm{~h}$. The isolates were identified based on colony morphology and biochemical reaction.

\section{Antimicrobial Resistance}

Antimicrobial susceptibility tests were performed by disk diffusion method on Muller Hinton agar $\left(\right.$ OXOID $\left.^{\circledR}\right)$ according to (Bauer et al., 1966) as recommended by the Clinical and Laboratory Standards Institute (CLSI) and the zone sizes were interpreted per CLSI guidelines (CLSI, 2008; 2013). The following 13 classes with 34 antimicrobial agents were tested: $\beta$-lactam penicillins: penicillin $\mathrm{G} \quad(10 \mathrm{U}) ; \quad \beta$-lactam aminopenicillin: amoxicillin $(10 \mu \mathrm{g})$ e ampicillin $(10 \mu \mathrm{g}) ; \beta$-lactam $/ \beta$ lactamase inhibitors combinations: amoxacillinclavulanic acid $(30 \mu \mathrm{g})$ and ampicillin-sulbactan $(20 \mu \mathrm{g})$; $\beta$-lactam penicillinase-stable penicillins: oxacillin $(1 \mu \mathrm{g})$ (just in gram positive); $\beta$-lactam cephems cephalosporin: first generation-cephalexin $(30 \mu \mathrm{g})$ and cephalothin $(30$ $\mu \mathrm{g})$ and $3 \mathrm{rd}$ generation - ceftriaxone $(30 \mu \mathrm{g}) ; \beta$-lactam cephems cephamycin: cefoxitin $(30 \mu \mathrm{g}) ; \quad \beta$-lactam carbapenems: imipenem $(10 \mu \mathrm{g})$ e meropenem $(10 \mu \mathrm{g})$; Glycopeptides: vancomycin $(30 \mu \mathrm{g})$ (just in gram positive); Polypeptides: polymyxin $(300 \mu \mathrm{g})$ (just in gram negative); Aminoglycosides: gentamycin (10 $\mu \mathrm{g})$, streptomycin $(10 \mu \mathrm{g})$, amikacin $(30 \mu \mathrm{g})$, neomycin $(30$ $\mu \mathrm{g})$ and tobramycin $(10 \mu \mathrm{g})$; Macrolides: 14-membered rings-erythromycin $(15 \mu \mathrm{g})$ and 15-membered ringsazithromycin $(15 \mu \mathrm{g})$; Lincosamides: clindamycin (2 $\mu \mathrm{g})$; Ansamycin: rifampin (5 $\mu \mathrm{g})$; Oxazolidinone: linezolid $(10 \mu \mathrm{g})$ (just in gram positive); Phenicols: chloranphenicol $(30 \mu \mathrm{g})$; Nitrofurantoin: nitrofurantoin (10 $\mu \mathrm{g})$; Fluoroquinolone: enrofloxacin $(5 \mu \mathrm{g})$, norfloxacin $(10 \mu \mathrm{g})$, ciprofloxacin $(5 \mu \mathrm{g})$ and levofloxacin $(5 \mu \mathrm{g})$; Tetracyclines: tetracycline $(30 \mu \mathrm{g})$ and doxycycline $(30 \mu \mathrm{g})$; Folate pathway inhibitors: sulfisoxazole (300 $\mu \mathrm{g})$ and sulfamethoxazoletrimethoprim $(25 \mu \mathrm{g})$ (NEWPROV®).

Phenotypic detection of multidrug-resistant strains of public health significance was performed by disk diffusion with: oxacillin to Methicillin-Resistant Staphylococcus spp. (MRS) (CLSI, 2008); erythromycin and clindamycin to Macrolide-Lincosamide-Streptogramin B (MLS(B)) of Staphylococcus spp. (Kim et al., 2004); synergism between amoxicillin-clavulonic acid and aztreonam, ceftazidime, cefotaxime, ceftriaxone, cefepime to Extended-Spectrum $\beta$-Lactamase (ESBL)-producing gram negative (Sousa Junior et al., 2004).

The Multiple Antibiotic Resistance (MAR) index was calculated by the number of resistant ratings over the total tested according (Krumperman, 1983).

\section{Staphylococcus spp. mecA Detection}

Presence of the resistance gene mecA of Staphylococcus spp. was examined for 22 strains of staphylococci by PCR. The DNA extraction was performed by (Doyle et al., 1987). $200 \mu \mathrm{L}$ of Tris-EDTA (TE) was added in to microtubes with isolated colonies and centrifuged at $8000 \times \mathrm{G}$ for $5 \mathrm{~min}$. The supernatant was discarded and the precipitation was suspended in $600 \mu \mathrm{L}$ of CTAB (Cetyl Trimethyl Ammonium Bromide) and $40 \mu \mathrm{L}$ of CIA (Chloroform/isoamyl alcohol), heated in a water bath at $65^{\circ} \mathrm{C}$ for $30 \mathrm{~min}$. Over $800 \mu \mathrm{L}$ of CIA was added and centrifuged at $12000 \times \mathrm{G}$ for $5 \mathrm{~min} .600 \mu \mathrm{L}$ of the supernatant was transferred to another microtube and was added $600 \mu \mathrm{L}$ of cold isopropanol. The mixture was incubated at $-20^{\circ} \mathrm{C}$ for $16 \mathrm{~h}$ and centrifuged at $13,500 \times \mathrm{g}$ for $20 \mathrm{~min}$ at $4^{\circ} \mathrm{C}$. The supernatant was discarded and the DNA was dried in laminar flow. The purified DNA was eluted in $200 \mu \mathrm{L}$ TE.

The PCR was performed with primers SMAswF (5'GAT GAT ACC TTC GTT CCA C-3' nt 622-640) and SMAswR (5'GTA TGT GCG ATT GTA TTG C-3' nt 917-935) that amplify a $314 \mathrm{bp}$, designed by Gene Runner software (version 3.0-Copyright (C) 1994 Hasting Software, Inc.). In the PCR $2 \mu \mathrm{L}$ of extracted DNA was added to $0.4 \mathrm{pmol}$ of each primers, $0,5 \mathrm{mM}$ each dNTP (Invitrogen Inc., Carlsbad, CA, USA), 1.5 unit of Taq DNA Polymerase (Invitrogen), 1x PCR buffer $(20 \mathrm{mM}$ Tris- $\mathrm{HCl} \mathrm{pH} 8.4$ and $50 \mathrm{mM} \mathrm{KCl}$ ), $3.0 \mathrm{mM} \mathrm{MgCl}_{2}$ and ultrapure sterile water to a final volume of $25 \mu \mathrm{L}$. The amplification consisted of the following time and temperature conditions: one step of $10 \mathrm{~min} / 95^{\circ} \mathrm{C}$ followed by 30 cycles at $30 \mathrm{sec} / 95^{\circ} \mathrm{C}, 30 \mathrm{sec} / 52^{\circ} \mathrm{C}$ and 1 $\min / 72^{\circ} \mathrm{C}$ and a final extension step of $10 \mathrm{~min} / 72^{\circ} \mathrm{C}$. Amplicons were analyzed by electrophoresis in a $1 \%$ agarose gel in TBE buffer pH 8.4 (89 mM Tris; $89 \mathrm{mM}$ boric acid; $2 \mathrm{mM}$ EDTA) stained with $0.5 \mu \mathrm{g} / \mathrm{mL}$ ethydium bromide and visualized under UV light. 


\section{Statistical Analysis}

The results were submitted to descriptive analysis to calculate the absolute and relative frequencies.

\section{Results}

The simple bacterial growth was found in 31 samples, in $13.88 \%(5 / 36)$ two bacterial strains were identified, totaling 41 bacterial strains isolated (Table 1).

A total of 1108 ratings antimicrobial agents were performed. The percentage of drug resistance was $28.70 \%(\mathrm{n}=318)$ and intermediate resistant, $5.95 \%(\mathrm{n}=$
66) totaling $34.66 \%(\mathrm{n}=384)$ of the assessments with partial or total resistance (Fig. 1).

The resistance to antimicrobial agents is contained in Table 2 and Fig. 2.

About 11 strains phenotypically characterized as MRS, 2 as MLSB-MRS and 2 as gram negative ESBL-producing (Proteus spp. and Pseudomonas spp.) were detected.

The MAR index medium was 0.293. Of the 41 strains evaluated, $53.66 \%(22 / 41)$ showed $\geq 0.2$ MAR and were considered multiresistant by (Krumperman, 1983) (Table 1).

Table 1. Frequency and percentage distribution and evaluation of Multiple Antibiotic Resistance (MAR) index found in bacterial pathogens of canine otitis

\begin{tabular}{|c|c|c|c|c|c|c|c|}
\hline \multicolumn{2}{|c|}{ Bacterial strains } & \multirow{2}{*}{$\frac{n}{27}$} & \multirow{2}{*}{$\begin{array}{l}\text { MAR } \\
\% \\
65,85\end{array}$} & \multirow{2}{*}{$\begin{array}{l}\mathrm{n} \\
\text { (médio) } \\
0.234\end{array}$} & \multirow{2}{*}{$\begin{array}{l}\mathrm{n} \\
\mathrm{MAR} \geq 0.2 \\
12\end{array}$} & \multirow{2}{*}{$\begin{array}{l}n \\
\text { MAR } \geq 0.5 \\
4\end{array}$} & \multirow{2}{*}{$\begin{array}{l}\text { MAR } \geq 0.75 \\
1\end{array}$} \\
\hline $\mathrm{G}^{+}$ & Staphylococcus spp. & & & & & & \\
\hline & Unidentified bacillus & 1 & 2,44 & 0.09 & 0 & 0 & 0 \\
\hline & Total & 28 & 68,29 & 0.229 & 12 & 4 & 1 \\
\hline \multirow[t]{11}{*}{ G - } & Enterobacteria & & & & & & \\
\hline & Halfnia alveii & 2 & 4,88 & 0.340 & 1 & 1 & 0 \\
\hline & Proteus spp. & 1 & 2,44 & 0.440 & 1 & 0 & 0 \\
\hline & Providencia spp. & 1 & 2,44 & 0.518 & 1 & 1 & 0 \\
\hline & Serratia spp. & 1 & 2,44 & 0.120 & 0 & 0 & 0 \\
\hline & Klebsiella spp. & 1 & 2,44 & 0.160 & 0 & 0 & 0 \\
\hline & Salmonella spp. & 1 & 2,44 & 0.448 & 1 & 0 & 0 \\
\hline & Total & 8 & 19,51 & 0.401 & 5 & 3 & 1 \\
\hline & Non-fermenting & & & & & & \\
\hline & Pseudomonas spp. & 5 & 12,19 & 0.478 & 5 & 2 & 0 \\
\hline & Total & 5 & 12,19 & 0.478 & 5 & 2 & 0 \\
\hline \multicolumn{2}{|c|}{ TOTAL } & 41 & 100,00 & 0.293 & 22 & 9 & 2 \\
\hline
\end{tabular}

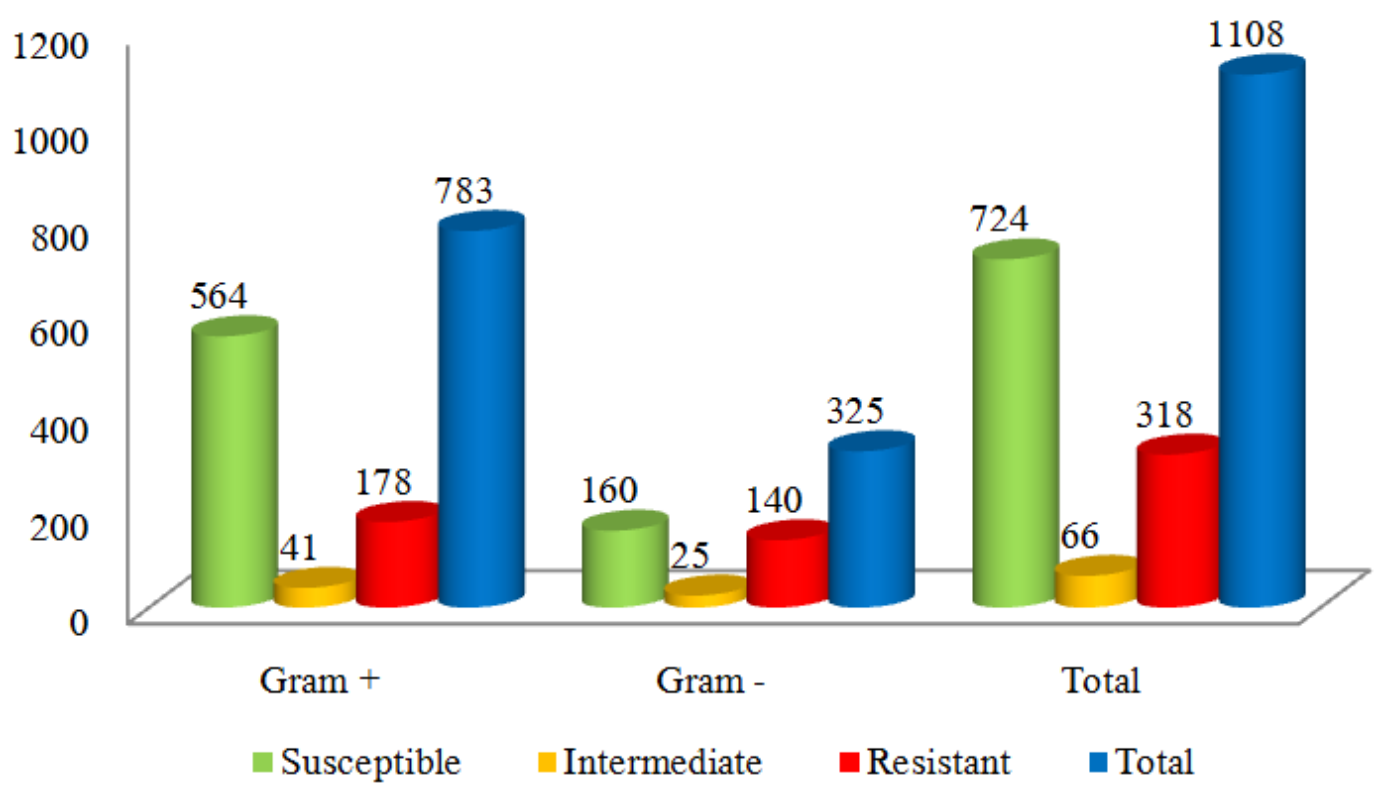

Fig. 1. Susceptibility tests of bacterial pathogens of canine otitis 


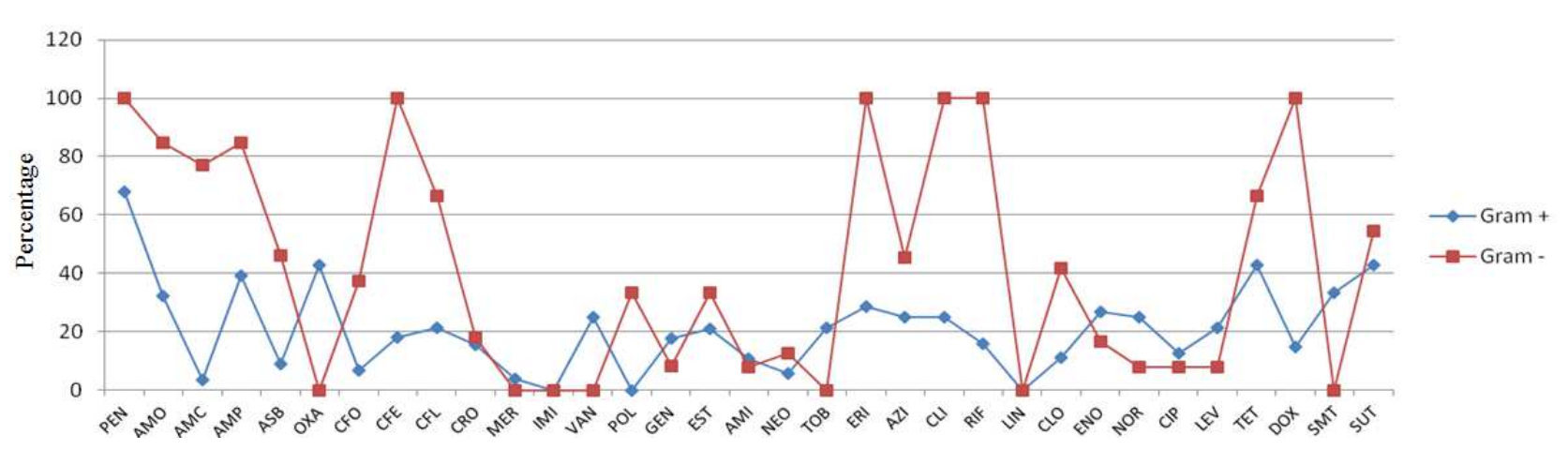

Fig. 2. Percentage of resistance to antimicrobial agents found in bacterial pathogens of canine otitis

Table 2. Frequency distribution and percentage of antimicrobial resistance found between bacterial strains obtained from canine otitis

\begin{tabular}{|c|c|c|c|c|c|c|c|c|c|}
\hline \multirow[b]{2}{*}{ Antimicrobial agents } & \multicolumn{3}{|c|}{ Gram positive } & \multicolumn{3}{|c|}{ Gram negative } & \multicolumn{3}{|c|}{ Total } \\
\hline & $\mathrm{R}$ & $\mathrm{n}$ & $\%$ & $\mathrm{R}$ & $\mathrm{n}$ & $\%$ & $\mathrm{R}$ & $\mathrm{n}$ & $\%$ \\
\hline Penicillin & 19 & 28 & 67.86 & 8 & 8 & 100 & 27 & 36 & 75.00 \\
\hline Amoxacillin & 9 & 28 & 32.14 & 11 & 13 & 84.62 & 20 & 41 & 48.78 \\
\hline Amoxacillin-clavulanic acid & 1 & 28 & 3.57 & 10 & 13 & 76.92 & 11 & 41 & 26.83 \\
\hline Ampicillin & 11 & 28 & 39.29 & 11 & 13 & 84.62 & 22 & 41 & 53.66 \\
\hline Ampicillin-sulbactan & 2 & 22 & 9.09 & 6 & 13 & 46.15 & 8 & 35 & 22.86 \\
\hline Oxacillin & 12 & 28 & 42.86 & 0 & 0 & 0.00 & 12 & 28 & 42.86 \\
\hline Cefoxitin & 1 & 15 & 6.67 & 3 & 8 & 37.50 & 4 & 23 & 17.39 \\
\hline Cephalexin & 4 & 22 & 18.18 & 6 & 6 & 100.00 & 10 & 28 & 35.71 \\
\hline Cephalothin & 6 & 28 & 21.43 & 8 & 12 & 66.67 & 14 & 40 & 35.00 \\
\hline Ceftriaxone & 4 & 26 & 15.38 & 2 & 11 & 18.18 & 6 & 37 & 16.22 \\
\hline Meropenem & 1 & 25 & 4.00 & 0 & 13 & 0.00 & 1 & 38 & 2.63 \\
\hline Imipenem & 0 & 21 & 0.00 & 0 & 13 & 0.00 & 0 & 34 & 0.00 \\
\hline Vancomycin & 7 & 28 & 25.00 & 0 & 0 & 0.00 & 7 & 28 & 25.00 \\
\hline Polymyxin B & 0 & 1 & 0.00 & 4 & 12 & 33.33 & 4 & 13 & 30.77 \\
\hline Gentamycin & 5 & 28 & 17.86 & 1 & 12 & 8.33 & 6 & 40 & 15.00 \\
\hline Streptomycin & 4 & 19 & 21.05 & 4 & 12 & 33.33 & 8 & 31 & 25.81 \\
\hline Amikacin & 3 & 28 & 10.71 & 1 & 13 & 7.69 & 4 & 41 & 9.76 \\
\hline Neomycin & 1 & 18 & 5.56 & 1 & 8 & 12.50 & 2 & 26 & 7.69 \\
\hline Tobramycin & 6 & 28 & 21.43 & 0 & 13 & 0.00 & 6 & 41 & 14.63 \\
\hline Erythromycin & 8 & 28 & 28.57 & 5 & 5 & 100.00 & 13 & 33 & 39.39 \\
\hline Azithromycin & 7 & 28 & 25.00 & 5 & 11 & 45.45 & 12 & 39 & 30.77 \\
\hline Clindamycin & 7 & 28 & 25.00 & 9 & 9 & 100.00 & 16 & 37 & 43.24 \\
\hline Rifampin & 4 & 25 & 16.00 & 12 & 12 & 100.00 & 16 & 37 & 43.24 \\
\hline Linezolid & 0 & 3 & 0.00 & 0 & 0 & 0.00 & 0 & 3 & 0.00 \\
\hline Chloranphenicol & 3 & 27 & 11.11 & 5 & 12 & 41.67 & 8 & 39 & 20.51 \\
\hline Enrofloxacin & 7 & 26 & 26.92 & 2 & 12 & 16.67 & 9 & 38 & 23.68 \\
\hline Norfloxacin & 7 & 28 & 25.00 & 1 & 13 & 7.69 & 8 & 41 & 19.51 \\
\hline Ciprofloxacin & 3 & 24 & 12.50 & 1 & 13 & 7.69 & 4 & 37 & 10.81 \\
\hline Levofloxacin & 6 & 28 & 21.43 & 1 & 13 & 7.69 & 7 & 41 & 17.07 \\
\hline Tetracycline & 12 & 28 & 42.86 & 8 & 12 & 66.67 & 20 & 40 & 50.00 \\
\hline Doxycycline & 4 & 27 & 14.81 & 9 & 9 & 100.00 & 13 & 36 & 36.11 \\
\hline Sulfametrin & 2 & 6 & 33.33 & 0 & 0 & 0.00 & 2 & 6 & 33.33 \\
\hline sulfamethoxazole-trimethoprim & 12 & 28 & 42.86 & 6 & 11 & 54.55 & 18 & 39 & 46.15 \\
\hline TOTAL & 178 & 783 & 22.73 & 140 & 325 & 43.08 & 318 & 1108 & 28.70 \\
\hline
\end{tabular}

About 4 of 22 Staphylococcus spp. strains were positive for $m e c A$ detection by PCR, genotypically characterized as MRS. Only one of these was resistant to oxacillin by disk diffusion, the others three were susceptible.

\section{Discussion}

The main micro-organisms found in this study were Staphylococcus spp. and Pseudomonas spp., with frequency of $65.85 \%$ and 12.19 respectively. In 1990 , (Oliveira et al., 2006a) also found similar etiology, being isolated $61.02 \%$ of Staphylococcus spp., $12.71 \%$ of Pseudomonas spp., still having $14.41 \%$ of Streptococcus spp. and other agents with low prevalence. (Oliveira et al., 2005) isolated 53.04\% of Staphylococcus spp. and $25.05 \%$ of Pseudomonas spp. (Oliveira et al., 2006a) isolated 55\% of Staphylococcus spp. and 10\% of Pseudomonas spp. (Oliveira et al., 2012) identified $46.75 \%$ of 
Staphylococcus spp. and $8.8 \%$ of Pseudomonas spp. Therefore it is observed that bacterial etiology of dog's ear canal infections is very similar, not depending on geographic region nor conditions such as animal race, age, or sex.

In this study antimicrobial drugs considered more resistant on isolated bacterial were penicillin $(\mathrm{R}=75.00 \%), \quad$ ampicillin $\quad(\mathrm{R}=53.66 \%), \quad$ tetracycline $(\mathrm{R}=50.00 \%), \quad$ amoxacillin $\quad(\mathrm{R}=48.78 \%) \quad$ and sulfamethoxazole-trimethoprim $(\mathrm{R}=46.15 \%)$.

Since 1990's, etiology and susceptibility of antimicrobials are studied in cases of canine otitis (Megid et al., 1990) found high sensitivity to gentamycin, ranging from 91.7 to $100 \%$ depending on the pathogen; amikacin with $90.6 \%$ of sensitivity to Staphylococcus spp.; erythromycin, ranging from $82 \%$ to Staphyloccocus and $100 \%$ to Streptoccocus; chloramphenicol with sensitivity of $100 \%$ to Streptococcus and Proteus, 82\% to Staphylococcus and $30 \%$ to Pseudomonas; tetracyclin with resistance ranging from 63.5 to $12.5 \%$ depending on the pathogen; and sulfonamid, with sensitivity of 22.2 to $25.7 \%$

Oliveira et al. (2005) found great susceptibility studying Coagulase-Positive Staphylococcus (CoPS) and negative (CoNS) and Pseudomonas as well. Joining the groups CoPS and CoNS, the most sensitive drug considered were: $100 \%$ cefoxitin; $\geq 90 \%$ amoxicillin + clavulonic acid, imipenem and netilmycin; $\geq 80 \%$ cefotaxin, ciprofloxacin and enrofloxacin; $\geq 70 \%$ tobramycin, cephalexin, gentamycin, chloramphenicol and amikacin; ranging from 70 to $20 \%$ oxacillin, neomycin, tetracycline and ampicillin, $\leq 40 \%$ penicillin. To Pseudomonas spp. the most sensitive drugs were ciprofloxacin (97.1\%), imipenem $(90.1 \%$, tobramycin $(85.9 \%)$ and enrofloxacin $(73.3 \%)$ while the least sensitive were $\beta$-lactam penicillins and cephalosporins, aminoglycosides (neomycin 19.2\%, gentamycin 53.3\% and amikacin 59.7\%) and chloramphenicol (5.4\%).

Oliveira et al. (2006a) studying the resistance of Staphylococcus intermedius detected the greatest resistance to erythromycin $(27.78 \%)$, penicillin G (25.96\%), tetracycline $(24.07 \%)$, ampicillin (16.67\%) and sulfamethoxazole $(11.11 \%)$. Drugs considered totally sensitive were amikacin, kanamycin, gentamycin, neomycin, tobramycin, imipenem, cephalothin, cephalexin, defoxitin and ticarcillin.

Oliveira et al. (2012) detected resistance of $2.66 \%$ to norfloxacin, $12.75 \%$ to gentamycin, $13.94 \%$ to ofloxacin, $19.78 \%$ to tobramycin, $12.63 \%$ to ciprofloxacin, $27.63 \%$ to cephalexin and $30.84 \%$ to neomycin.

Data obtained in this study corroborate with most of other studies performed with the profile and etiology of resistance to antimicrobials, being found a low prevalence of resistance in all of them to most of antimicrobials drugs to Staphylococcus and greater resistance to Pseudomonas justified by the high intrinsic resistance of this microorganism. 13 antimicrobial classes were tested in this study, totalizing 34 antimicrobial agents of tested.

$\beta$-lactam penicillins drugs (penicillin $\mathrm{R}=75.00 \%$ ) and aminopenicillin (ampicillin $\mathrm{R}=53.66 \%$ and amoxacillin $\mathrm{R}=48.78 \%$ ) showed high level of resistance, however when associated with $\beta$-lactamase inhibitors (sulbactan with ampicillin $\mathrm{R}=22.86 \%$ and clavulonic acid with amoxacillin $\mathrm{R}=26.83 \%$ ) it was noted the improvement in sensitivity to drugs in $57.41 \%$ and $45 \%$ of the cases respectively. So this study recommends the association between aminopenicillin with $\beta$-lactamase inhibitors.

The semi synthetic oxacillin $\beta$-lactam drug is, according to CLSI (2008), a drug for pre-editting of resistance in Staphylococcus spp. to all $\beta$-lactam, associated to resistance to cefoxitin. According to Kim et al. (2012) and Cartwright et al. (2013) resistance to oxacillin and cefoxitin shows phenotypically the presence of $m e c A$ gene. On the other hand resistance to cefoxitin with sensitivity to oxacillin, shows the presence of mecC gene, which is responsible for the production of a protein that links additional penicillin (PBP2a) that provides low affinity of linking to $\beta$-lactam drugs. Staphylococcus spp. that carries this gene is called MRS. Several studies show the existence of MRS in Medicine Veterinary.

In this study 11 (40.74\%) of 27 staphylococci strains were resistant to oxacillin. However, only 4 carried the $m e c A$ gene of which 3 were oxacillin-susceptible. Nevertheless, all four will be reported as MRS, making $14.81 \%(4 / 27)$. These results show that the phenotypic detection of oxacillin-resistance in not totally related to the presence of $m e c A$ gene as well as there are possible other genes of resistance to $\beta$-lactam agents that not only the mecA, gene being so important as this.

Tested $\beta$-lactam cephalosporins agents showed low resistance level, ranging from $35.00 \%$ to cephalothin, $35.71 \%$ cephalexin and $16.22 \%$ to ceftriaxone. However they showed great resistance in gram negatives (cephalexin and cephalothin).

Carbapenems have a chemical structure similar to penicillin, but with chemical characteristics which give them greater affinity to PBPs, showing greater potency and an expanded antibacterial spectrum. Resistance to carbapenems is already considered a problem to public health in many countries (Ribeiro, 2013). Carbapenems evaluated in this study have shown $2.63 \%$ of resistance to meropenem (only in gram positive). Although there are no rules that forbid the use of carbapenems in Veterinary Medicine, these antimicrobials must be used very carefully in order to avoid pressure in selecting resistant clones and resistance transmission to other bacteria, potentially some contact with humans.

After the discovery of multiresistant gram positive bacteria, specially the MRS, antimicrobial class of glycopeptides vancomycin and teicoplamin have been 
the last alternative for the treatment against these micro-organisms for many years in Medicine (WHO, 2009). In Veterinary Medicine the resistance to glycopeptides has been hardly studied due to little use. According to Haenni et al. (2010) and Monchique (2013), VISA strains (Vancomycin Intermediate Resistance Staphylococcus aureus) and VRS (Vancomycin-Resistant Staphylococcus aureus) have not been reported in Veterinary Medicine yet. The results of this study, using disk-diffusion show that in 27 samples of Staphylococcus spp. 21 were susceptible in vitro to vancomycin and 7 need new evaluation through antimicrobial test by Minimum Inhibitory Concentration (MIC).

Aminoglycoside class showed one of the best level of susceptibility in this study, ranging from $7.69 \%$ to $25.81 \%$, as well as phenicols.

Macrolides, Lincosamides and Streptogramin B form MLSB group of antibiotics, although having different formulas, they present the same mechanism action, inhibiting the protein synthesis through the link to the $23 \mathrm{~S}$ receptor of rRNA that takes part of the $50 \mathrm{~S}$ subunity of the bacterial ribosome. Since 1956, soon after the introduction of erythromycin in the market, Staphylococcus aureus resistance to MLSb group (Leclercq, 2002) has already been seen. In Medicine Veterinary, clindamycin is largely used, also indicated to infections caused by Staphylococcus, mainly the MRS (Fiebelkorn et al., 2013). However, Kim et al. (2004) while analysing the presence of resistance to MLSb group in Staphylococcus aureus found out that 97\% of MRSA (Meticillin-Resistant Staphylococcus aureus) showed resistance to at least one of the antibiotics of this group. Epidemiologically, the crossed-resistance among these 3 classes of antimicrobials is very important Dipersio and Dipersio (2005) once they are largely used in Veterinary Medicine taking to the increase of resistance of animal origin.

The tested macrolides showed resistance of $39.39 \%$ to erythromycin and $30.77 \%$ to azithromycin. Resistance to clindamycin was found in $43.24 \%$ of the studied samples. $11.11 \%(03 / 27)$ of Staphylococcus spp. resistant to MLSb group were detected with the two tested drugs, two of them being characterized as MRS.

The class of fluoroquinolones, according to CLSI (2008) must be reported together, where resistance to a drug indicates the resistance of the whole class. Percentages of resistance of $10.81 \%$ to cyprofloxacin, $19.51 \%$ to norfloxacin, $23.68 \%$ to enrofloxacin and $17.07 \%$ to levofloxacin were found, showing greater significant resistance in gram positives, being these drugs of great value for the empirical treatment by gram negative bacteria.

\section{Conclusion}

Major bacterial pathogens were Staphylococcus spp. (65.85\%), Pseudomonas spp. (12.19\%) and Enterobacterial species (19.51\%). 53.66\% of these isolates were considered multiresistant. The percentage of drug resistance was $34.66 \%(\mathrm{n}=384)$ of the assessments with partial or total resistance. Antimicrobial agents considered most resistant in the strains studied were penicillin $(75.00 \%)$, tetracyclin (50.00\%), amoxicillin (48.78\%), trimethoprimsulfamethoxazole $(46.15 \%)$, clindamycin and rifampin (43.24\%). 11 strains were phenotypically characterized as MRS, 4 genotypically as MRS, 2 as MLSB-MRS and 2 as gram negative ESBL-producing. All these strains are considered of importance in public health.

\section{Acknowledgment}

We thanks the staff of the Veterinary Hospital of State University of Maringa.

\section{Funding Information}

We also thanks State University of Maringa and Federal University of Parana, Campus Palotina in special to Animal Science Pós-graduate Program for providing financial aid to conduct this study. The researchers are grateful for the support by Fundação Araucária - PR - BR.

\section{Author's Contributions}

R.A.P. Sfaciotte: Conducted the experiment, summarized the date.

J.T. Bordin and V.K.C. Vignoto: contributed the the execution of the study.

P.M. Munhoz: Reviewed statistical analysis procedures.

A.A. Pinto, M.J.B. Barbosa and R.M. Cardozo: Contibuted to the experiment analysis and manuscript preparation.

S.C. Osaki: Contributed to the planning and execution of the study and the laboratory analysis.

S.R. Wosiacki: Conceptualized and supervised the research, drafted the manuscript and ran statistical tests. All authors have read and approved the manuscript.

\section{Ethics}

All procedures illustrated were undertaken under a project licence approved by Committee of Ethical Conduct in the use of Animals in Experimentation, State University of Maringá, with reference number 064/14. 


\section{Conflict of Interests}

The authors declare that there is no conflict of interests regarding the publication of this paper.

\section{References}

Bauer, A.W., W.M.M. Kirby, J.C. Sherris and M. Turck, 1966. Antibiotic susceptibility testing by a standardized single disk method. Am. J. Clin. Pathol., 45: 493-496.

Cartwright, E.J.P., G.K. Paterson, K.E. Raven, E.M. Harrison and T. Gouliouris et al., 2013. Use of Vitek 2 antimicrobial susceptibility profile to identify mec $\mathrm{C}$ in methicillin-resistant Staphylococcus aureus. J. Clin. Microbiol., 51: 2732-2734. DOI: 10.1128/JCM.00847-13

CLSI, 2008. M31-A3. Performance standards for antimicrobial disk and dilution susceptibility tests for bacteria isolated from animals: Approved standard. Clinical and Laboratory Standards Institute, Wayne, Pa, USA.

CLSI, 2013. M100-S23. Performance standards for antimicrobial susceptibility testing: 23rd informational supplement, Clinical and Laboratory Standards Institute, Wayne, Pa, USA.

Dipersio, J.R. and L.P. Dipersio, 2005. Update on the prevalence and spread of macrolide and lincosamide-resistant staphylococcal and streptococcal species. Rev. Med. Microbiol., 16: 117-123. DOI: 10.1097/01.revmedmi.0000174306.26027.e3

Doyle, J.J., J.L. Doyle and L.H.B. Hortorium, 1987. Isolation of plant DNA from fresh tissue. Focus, 12: 13-15.

Fiebelkorn, K.R., S.A. Crawford, M.L. Mcelmeel and J.H. Jorgensen, 2003. Practical disk diffusion method for detection of inducible clindamycin resistance in Staphylococcus aureus and coagulase-negative staphylococci. J. Clin. Microbiol., 41: 4740-4744. DOI: $10.1128 / \mathrm{JCM} .41 .10 .4740-4744.2003$

Haenni, M., H. Targant, K. Forest, C. Sévin and J. Tapprest et al., 2010. Retrospective study of necropsy-associated coagulase-positive staphylococci in horses. J. Vet. Diagn. Invest., 22: 953-956. DOI: 10.1177/104063871002200617

Hariharan, H., M. Coles, D. Poole, L. Lund and R. Page, 2006. Update on antimicrobial susceptibilities of bacterial isolates from canine and feline otitis externa. Can. Vet. J., 47: 253-255.

Ishii, J.B., J.C. Freitas and M.V.B. Arias, 2011. Resistance of bacteria isolated from dogs and cats at Veterinary Hospital of Universidade Estadual de Londrina (2008-2009). Pesq. Vet. Bras., 31: 533-537. DOI: $10.1590 / \mathrm{S} 0100-736 \mathrm{X} 2011000600013$
Kim, C., C. Milheiriço, S. Gardete, M.A. Holmes and M.T.G. Holden et al., 2012. Properties of a novel PBP2A protein homolog from Staphylococcus aureus strain LGA251 and its contribution to the betalactam-resistant phenotype. J. Biol. Chemistry, 287: 36854-36863. DOI: 10.1074/jbc.M112.395962

Kim, H.B., B. Lee, H.C. Jang, S.H. Kim and C.I. Kang et al., 2004. A high frequency of macrolidelincosamide-streptogramin resistance determinants in Staphylococcus aureus isolated in South Korea. Microbial Drug Resistance, 10: 248-54.

DOI: $10.1089 / \mathrm{mdr} .2004 .10 .248$

Krumperman, P.H., 1983. Multiple antibiotic resistance indexing of Escherichia coli to identify high-risk source of fecal contamination of foods. Applied Environ. Microbiol., 46: 165-170.

Leclercq, R., 2002. Mechanisms of resistance of macrolides and lincosamides: nature of the resistance elements and their clinical implications. Clin. Infect. Dis., 34: 482-92. DOI: 10.1086/324626

Megid, J., J.C. Fretias, E.E. Müller and L.L.S. Costa, 1990. Otite canina: etiologia, sensibilidade antibiótica e suscetibilidade animal. Semina, 11: 45-48. DOI: $10.5433 / 1679-0359.1990 \mathrm{v} 11 \mathrm{n} 1 \mathrm{p} 45$

Monchique, C.R.O., 2013. Evolução da resistência aos antibióticos em Staphylococcus spp. :1999 a 2006. Dissertação de Mestrado Integrado em Medicina Veterinária, Faculdade de Medicina Veterinária, Universidade de Lisboa, Lisboa, Portugal.

Oliveira, L.C., C.A.L. Leite, R.S.N. Brilhante and C.B.M. Carvalho, 2006b. Etiology of canine otitis media and antimicrobial susceptibility of coagulasepositive staphylococci in Fortaleza city, Brazil. Braz. J. Microbiol., 37: 144-147. DOI: $10.1590 / \mathrm{S} 1517-83822006000200009$

Oliveira, L.C., C.M.O. Medeiros, I.N.G. Silva, A.J. Monteiro and C.A.L. Leite et al., 2005. Antimicrobial sensitivity of bacteria from otitis externa in dogs. Arq. Bras. Med. Vet. Zootec., 57: 405-408. DOI: 10.1590/S0102-09352005000300021

Oliveira, L.C., R.S.N. Brilhante, A.M.S. Cunha and C.B.M. Carvalho, 2006a. Profile of microorganisms isolated from dogs with associated media and extern otitis. Arq. Bras. Med. Vet. Zootec., 58: 1009-1017. DOI: $10.1590 / \mathrm{S} 0102-09352006000600006$

Oliveira, V.B., M.G. Ribeiro, A.C. Almeida, A.C. Paes, L.A.Z. Condas, G.H.B. Lara, M.M.J. Franco, M.C. Fernandes, F.J.P. Listoni, 2012. Etiologia, perfil de sensibilidade aos antimicrobianos e aspectos epidemiológicos na otite canina: estudo retrospectivo de 616 casos. Semina: Ciências Agrárias, 33: 2367-2374. DOI: $10.5433 / 1679-0359.2012$ v33n6p 2367

Petrov, V., G. Mihaylov, I. Tsachev, G. Zhelev and P. Marutsov et al., 2013. Otitis externa in dogs: microbiology and antimicrobial susceptibility. Revue Méd. Vét., 164: 18-22. 
Ribeiro, V.B., 2013. Detecção de resistência aos carbapenêmicos e avaliação da produção de Klebsiella pnemoniae carbapenemase (kpc) em isolados clínicos da família Enterobacteriaceae. Programa de PósGraduação em Ciências Farmacêuticas, Universidade Federal do Rio Grande do Sul.

Sousa Junior, M.A., E.V. Ferreira and G.C. Conceição, 2004. Betalactamase de Espectro Estendido (ESBL): um importante mecanismo de resistência bacteriana e sua detecção no laboratório clínico. NewsLab, 63: 152-174.
WHO, 2009. WHO list of critically important antimicrobials for human medicine. Geneva: World Health Organization. 